Egyptian J. Anim. Prod. (2014) 51(3):216-224

\title{
Efficiency of Using Different Methionine Sources in Low Methionine Diets of (Oreochromis niloticus) Fingerlings
}

\author{
K. Mohamed ${ }^{* 1}$ and F. Liebert ${ }^{2}$ \\ ${ }^{1}$ Department of Animal and Fish Resources, Faculty of Agriculture, Suez Canal University 41522 Ismailia, Egypt \\ ${ }^{2}$ Division of Animal Nutrition Physiology, Department of Animal Science,Georg-August-University, Goettingen, \\ Germany \\ *E-mail: khelo20022002@yahoo.com
}

\section{SUMMARY}

An experiment was conducted to evaluate the use of different crystalline methionine sources to optimize amino acid profiles and its effect on growth performance and feed utilization in feeds of all male tilapia $O$.

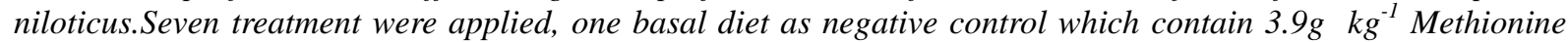
(MET) and diets (2-6) were supplemented with two levels of MET dietary (0.15-0.30\%) of DL- MET, novel METIand MET2 at a constant dietary cysteine level of $3.9 \mathrm{~g} \mathrm{~kg}^{-1}$, respectively. The tested diets formulated to contain $28 \%$ crude protein and 18.7 MJ GE, applied in 28 fiberglass tanks, 25 Nile tilapia fingerlings (13.5 \pm $0.40 \mathrm{~g}$ ). Growth performance and feed efficiency were improved significantly for tilapia fed on diets supplemented by different MET products compared to non supplemented diet (control). The present study clearly shows that optimizing the amino acid profile by inclusion of a single crystalline amino acid (crystalline MET) does not give the same protein utilization as that of a diet in which the amino acids are mainly protein bound. Diet containing MET1 improved protein utilization than DL- MET or MET2.

Keywords: amino acid, efficiency, requirement, growth performance, feed utilization, tilapia

\section{INTRODUCTION}

As fish meal is an expensive component of commercial fish feeds and beyond sustainable limits (Cho and Bureau, 2001), fish nutrition investigations are mainly directed towards reducing feed cost by manipulating the feed formulation. Most published research focused on plant protein sources such as soybean meal (Wilson et al., 2004), cottonseed meal (Lim, 1996) and sunflower meal (Mainaet al., 2003). However, plant feedstuffs mostly associate with lower nutrient concentrations, insufficient levels of amino acids (AA) (e.g. lysine and methionine), antinutritional factors and poor palatability (Tacon and Jackson, 1985 and Denstadliet al., 2006). Furthermore, methionine is one of the most limiting essential AA in plant protein sources for fish diet formulation (Goff and Gatlin 2004; Alam et al.2005; Zhou et al., 2006).Therefore, it is expected that extra methionine has to be added to plant protein based diets in order to promote optimal growth and health of fish. Thus, to maximize the utilization of plant protein sources, especially those that have low methionine levels, the determination of methionine requirement is important for the development of costeffective fish feeds. In this context, it is also relevant to investigate the efficiency of methionine supplementation to practical diets that are expected to be deficient in methionine supply. To date, amino acid requirement studies in fish mostly make use of doseresponse effects on growth, nutrient deposition and/or several physiological criteria and utilize graded supplementation of the crystalline amino acid under study (Shearer 2000; Wilson 2003 and Kaushik and Seiliez, 2008). Several studies have been conducted to determine the methionine requirement and it was found to be $0.1,0.5,0.53$ and $0.75 \%$ of diet according to Ogunjiet al. (2005), Kasper et al. (2000), Jackson and Capper (1982) and Santiago and Lovell (1988), respectively, in addition to the total sulphur amino acid requirement of juvenile tilapia was $0.85 \%$ of diet as reported by Nguyen and Davis (2008). Generally, high variation was yielded due to the observed requirement concentration in the final diets. Different approaches are one factor of influence. Supplementation technique requires significant doseresponse effects coming from several equally spaced increments of the supplemented limiting AA (Cowey, 1992). Several studies indicated the importance of the adequacy of the breakpoint analysis for obtaining reliable data (Robbins et al., 1979 and Were, 1989). In addition, overdosing of individual amino acids may deliver amino acid imbalances (Wilson, 2003 and Hellandet al., 2006). To overcome several disadvantages of supplementation technique, the current study concluded quantitative methionine requirements in juvenile tilapia by use of a nonlinear $\mathrm{N}$-utilization model. Making use of nonlinear $\mathrm{N}$ utilization models and adequate mathematical description of protein deposition as a function of the intake of the first limiting dietary amino acid is one of the important approaches mostly applied for modelling of AA requirements in fish (Liebertet al., 2006; Liebert and Benkendorff, 2007a, b and Liebert, 2009). The current study was conducted to measure the dietary efficiency of protein-bound Met or as supplemented AA for further evaluation of Met requirement data in tilapia feeding. 
MATERIAL AND METHODS

Table 1. Composition $\left(\mathrm{g} \mathrm{kg}^{-1}\right)$ of Tilapia diets limiting in methionine supply

\begin{tabular}{|c|c|c|c|c|c|c|c|}
\hline \multirow{2}{*}{ Ingredients } & \multicolumn{7}{|c|}{ Diet } \\
\hline & 1 & 2 & 3 & 4 & 5 & 6 & 7 \\
\hline Corn & 240 & 240 & 240 & 240 & 240 & 240 & 240 \\
\hline Soybean meal & 250 & 250 & 250 & 250 & 250 & 250 & 250 \\
\hline $\mathrm{SPC}^{1}$ & 150 & 150 & 150 & 150 & 150 & 150 & 150 \\
\hline Peas & 100 & 100 & 100 & 100 & 100 & 100 & 100 \\
\hline bean & 40 & 40 & 40 & 40 & 40 & 40 & 40 \\
\hline Fish oil & 45 & 45 & 45 & 45 & 45 & 45 & 45 \\
\hline Vit Min Mix ${ }^{2}$ & 10 & 10 & 10 & 10 & 10 & 10 & 10 \\
\hline $\mathrm{MCP}^{3}$ & 10 & 10 & 10 & 10 & 10 & 10 & 10 \\
\hline $\mathrm{CaCO}_{3}{ }^{4}$ & 7 & 7 & 7 & 7 & 7 & 7 & 7 \\
\hline $\mathrm{CMC}^{5}$ & 20 & 20 & 20 & 20 & 20 & 20 & 20 \\
\hline L-Thr & 0.7 & 0.7 & 0.7 & 0.7 & 0.7 & 0.7 & 0.7 \\
\hline DL- Met & - & 1.5 & 3 & - & - & - & - \\
\hline Met- $(\mathrm{P} 1)^{6}$ & - & - & - & 1.5 & 3 & - & - \\
\hline Met- $(\mathrm{P} 2)^{7}$ & - & - & - & - & - & 1.5 & 3 \\
\hline Wheat starch & 127.3 & 125.8 & 124.3 & 125.8 & 124.3 & 125.8 & 124.3 \\
\hline Total & 1000 & 1000 & 1000 & 1000 & 1000 & 1000 & 1000 \\
\hline \multicolumn{8}{|c|}{ Chemical composition } \\
\hline Crude protein & 275 & 272 & 277 & 277 & 275 & 277 & 276 \\
\hline Crude lipid & 82.0 & 69.3 & 69.5 & 70,9 & 68.6 & 68.2 & 93 \\
\hline Ash & 67.7 & 67.5 & 67.0 & 66.9 & 67.5 & 66.6 & 66.3 \\
\hline Crude fibre & 49.3 & 49.2 & 52.7 & 53.0 & 54.0 & 52.6 & 51.8 \\
\hline $\mathrm{N}$-free extract & 526 & 542 & 533.8 & 532.2 & 534.9 & 535.6 & 512.9 \\
\hline Gross energy $\left(\mathrm{kJ} \mathrm{g}^{-1}\right)$ & 18.8 & 18.2 & 18.3 & 18,4 & 18.2 & 18.3 & 19.2 \\
\hline $\mathrm{P}: \mathrm{E}\left(\mathrm{g} \mathrm{MJ}^{-1}\right)$ & 14.7 & 14.9 & 15.1 & 15.1 & 15.1 & 15.2 & 14.4 \\
\hline Methionine & 3.9 & 5.5 & 7.1 & 5.4 & 7.0 & 5.5 & 7.0 \\
\hline Methionine+cystine & 7.8 & 9.4 & 1.10 & 9.4 & 1.11 & 9.6 & 1.11 \\
\hline Lysine & 16.1 & 16.0 & 16.0 & 16.1 & 15.9 & 16.1 & 16.0 \\
\hline Threonine & 11.5 & 11.5 & 12.3 & 12.2 & 11.3 & 11.8 & 11.2 \\
\hline
\end{tabular}

1- Soybean protein concentrate

2- Vitamin and mineral mix (provided per $\mathrm{kg}$ of diet): $\mathrm{MnSO}_{4}, 40 \mathrm{mg} ; \mathrm{MgO}, 10 \mathrm{mg} ; \mathrm{K}_{2} \mathrm{SO}_{4}, 40 \mathrm{mg} ; \mathrm{ZnCO}_{3}, 60 \mathrm{mg}$; $\mathrm{KJ}, 0.4$ mg; $\mathrm{CuSO}_{4}, 12 \mathrm{mg}$; ferric citrate, $250 \mathrm{mg}$; $\mathrm{Na}_{2} \mathrm{SeO}_{3}, 0.24 \mathrm{mg}$; Co, $0.2 \mathrm{mg}$; vitamin A, 4000 IU; vitamin B6, 30 mg; vitamin D3, $400 \mathrm{IU}$; vitamin E, $400 \mathrm{mg}$; vitamin B12, $80 \mu \mathrm{g}$; vitamin B1, $30 \mathrm{mg}$; vitamin B2, $40 \mathrm{mg}$; vitamin K3, $12 \mathrm{mg}$; folic acid, $10 \mathrm{mg}$; biotin, $3 \mathrm{mg}$; pantothenic acid, $100 \mathrm{mg}$; inositol, $50 \mathrm{mg}$; ascorbic acid, $500 \mathrm{mg}$.

3- Calsium carbonate

4 - Monocalsium phosphate

5-Carboxyl methyl cellulose

6,7- Evonik Degussa GmbH, RodenbacherChaussee 4, 63457 Hanau, Germany

\section{Experimental diets:}

Seven iso-nitrogenous and iso-caloric diets were formulated from practical ingredients to contain almost $28 \%$ crude protein 18.7 MJ GE (Table1).The diets were based on plant protein sources (Corn, Soybean meal, soybean-condensed protein, peas and bean). One basal diet as negative control which contain $3.9 \mathrm{~g} \mathrm{~kg}^{-1}$ Methionine and 6 diets were supplemented with two levels of methionine dietary (0.15-0.30\%) DL-methionine, novel methionine P1 and methionine P2 (Six diets were prepared by adding DL-Met, or two Met sources consisting of Met dimmers, including either DD-,LL-,DL-, and LD-Met 
dimmers(MET1) or mixture of DL- and LD-Met (MET2) at a constant dietary cystine level of $3.9 \mathrm{~g} \mathrm{~kg}^{-}$ ${ }^{1}$, respectively. Crystalline amino acid (L.Therionine) was added to all diets to cover the amino acid requirements of tilapia according to (NRC 2011).Fish oil was added as a major dietary lipid source to maker all diets isolipidic. Wheat starch was used as additional source of energy to adjust the energy content of the diets. The vitamin mixture used was a commercial mixture of (Deutsche Vilomix Tiernährung $\mathrm{GmbH}$ ) which was added to all experimental diets at a constant level of $1 \%$. The wet mixture was passed through granule machine with 2 $\mathrm{mm}$ diameter. The produced pellets were dried at room temperature for three days (approximately $10 \%$ moisture was achieved). The dried pellets were stored in a cool room at $2{ }^{\circ} \mathrm{C}$.

\section{Experimental conditions:}

Experimental fish were stocked in a semi-closed in-door water recirculation system with 28 circular plastic tanks (250-L/tank). Each tank was continuously supplied with a mixture of fresh water (approximately 10\%) and biologically filtered fresh water. The photoperiod (12h light: $12 \mathrm{~h}$ dark) were regulated. The water temperature was recorded daily and other quality parameters including $\mathrm{pH}$, ammonia and $\mathrm{NO}_{2}$ were recorded weekly.

\section{Experimental fish:}

Tilapia, Oreochromis niloticus were obtained from Department of Animal Science, Divison of Animal Breeding and Animal Genetics, Göttingen University, Germany. Fish were acclimated to laboratory conditions for two weeks before being distributed into plastic tank of 250-L water capacity each. Fish with an average of $13.5+0.4 \mathrm{~g}$ initial body weight were distributed into 28 circular experimental tanks four replicate groups of 25 fish each. The experiment lasted 56 days. All fish in each tank were weighed every 14 days. During the growth period, each diet was offered to fish groups by hand, 4 meals/day.

\section{Sample collection:}

At the beginning of the experiment, ten fish were analyzed for body composition. Three fish/ tank were sampled at the end of experiment, killed by anestheticoverdose (Ethylene-glycol-monophenylether), autoclaved $\left(110^{\circ} \mathrm{C}, 3 \mathrm{~h}\right)$, homogenized with lab mixer and stored at $-20{ }^{\circ} \mathrm{C}$ for subsequent chemical analysis. The feed ingredients and diets, which were used in the experimental study, were also chemically analyzed according to the method described by NAUMANN and BASSLER (1976 1997 ) in duplicates. Dry matter determination used an oven at $110^{\circ} \mathrm{C}$ (Memmert) until constant weight; crude ash was detected by $4 \mathrm{~h}$ ashing at $600{ }^{\circ} \mathrm{C}$ in a furnace muffle (Thermicon P; Heraeus Holding). A nitrogen auto-analyzer (FP-2000; Leco) was utilized for crude protein determination using the Dumasmethod $(\mathrm{N} \times 6.25)$. Ether extract was determined by extraction with petroleum ether according to the Soxhlet-procedure following $\mathrm{HCl}$-hydrolysis of the feed samples. Gross energy of the diets was calculated due to NRC (1993), based on crude nutrient analyses. Amino acids analyses (except tryptophan) were conducted by ion-exchange chromatography (LC 3000, Biotronic, EppendorfNetheler-Hinz GmbH, Hamburg, Germany) following acid hydrolysis with and without an oxidation step for determination of sulphur-containing Amino acids.

\section{Statistical analysis:}

All data of growth performance and feed utilization were analyzed by one-way analysis of variance (ANOVA) using the general linear models procedure of statistical analysis system (SPSS) version 17, (2009). Duncan's multiple range test (Duncan, 1955) was used to resolve differences among treatment means at 5\% significant level using the following model. $\mathrm{Yij}=\mu+\mathrm{Ti}+\mathrm{Eij}$

Where

$\mu=$ over all mean.

Yij =the observation of the individual from $\mathrm{T}$ treatment

$\mathrm{Ti}=$ the fixed effect of $\mathrm{T}$ diet.

Eij $=$ the experimental random error associated with individual $\mathrm{J}$.

The model for assessing the dietary AA-efficiency

According to equations 1 and 2, the applied model basically describes body nitrogen retention (NR) depending on nitrogen intake (NI) and dietary protein quality (b):

(1) $\mathrm{NR}=\mathrm{NR}_{\max } \mathrm{T}\left(1-\mathrm{e}^{-\mathrm{b} \cdot \mathrm{NI}}\right)$

(2) $\mathrm{ND}=\mathrm{NR}_{\max } \mathrm{T}\left(1-\mathrm{e}^{-\mathrm{b} \cdot \mathrm{NI}}\right)-\mathrm{NMR}$

Where:

$$
\begin{aligned}
& \mathrm{NR}=\text { daily } \mathrm{N} \text {-retention }(\mathrm{ND}+\mathrm{NMR}) \\
& {\left[\mathrm{mg} / \mathrm{BW}_{\mathrm{kg}}^{0.67}\right]}
\end{aligned}
$$
requirement

$$
\begin{aligned}
& {\left[\mathrm{mg} / \mathrm{BW}_{\mathrm{kg}}^{0.67}\right] \quad \mathrm{NI}=\text { daily } \mathrm{N}-} \\
& \text { intake } \\
& \text { intake }\left[\mathrm{mg} / \mathrm{BW}_{\mathrm{kg}}{ }^{0.67}\right] \\
& \mathrm{NR}_{\max } \mathrm{T}=\text { Theoretical maximum for } \\
& \text { daily N-retention } \quad\left[\mathrm{mg} / \mathrm{BW}_{\mathrm{kg}}{ }^{0.67}\right] \\
& \mathrm{ND}_{\max } \mathrm{T}=\mathrm{NR}_{\max } \mathrm{T}-\mathrm{NMR} \\
& \mathrm{b}=\text { slope of function (1) and (2), } \\
& \text { respectively } \\
& \text { (Indicating the dietary protein quality }
\end{aligned}
$$

Estimation procedure of the model parameters $\mathrm{NR}_{\max } \mathrm{T}, \mathrm{ND}_{\max } \mathrm{T}$, and NMR was reported for all male juvenile O. niloticus(Liebert et al., 2006) and also utilized for the current investigations (NMR=70mg /

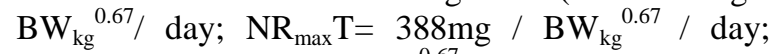
$\mathrm{ND}_{\max } \mathrm{T}=318 \mathrm{mg} / \mathrm{BW}_{\mathrm{kg}}^{0.67} /$ day). Following 
logarithmization and transformation of equation (1), further model parameters are obtained:

(3) $\mathrm{b}=\left[\ln \mathrm{NR}_{\max } \mathrm{T}-\ln \left(\mathrm{NR}_{\max } \mathrm{T}-\mathrm{NR}\right)\right]$ : NI

According to equation (3) the model parameter " $b$ " is determined, indicating the dietary protein quality. Equation (4) calculates the required NI for a defined NR depending on feed protein quality (b):

$$
\begin{aligned}
& \text { (4) } \mathrm{NI}=\left[\ln \mathrm{NR}_{\max } \mathrm{T}-\ln \left(\mathrm{NR}_{\max } \mathrm{T}-\right.\right. \\
& \mathrm{NR}): \mathrm{b}
\end{aligned}
$$

The fundamental relationship between intake of the limiting amino acid (LAAI) and NR provides equation (5):

$$
\text { (5) } \quad \mathrm{LAAI}=\left[\operatorname{lnNR} R_{\max } \mathrm{T}-\ln \left(\mathrm{NR}_{\max } \mathrm{T}-\right.\right.
$$
$\mathrm{NR})]:\left[16 \cdot \mathrm{bc}^{-1}\right]$

Where

$$
\begin{aligned}
& \text { LAAI = daily intake of the LAA } \\
& \text { (Indicating the requirement } \\
& \text { dependent on NR and } \mathrm{bc}^{-1} \text { ) } \\
& \mathrm{bc}^{-1}=\text { Slope between LAA- }
\end{aligned}
$$

concentration (c) and feed protein quality (b)

(The slope is indicating the efficiency of dietary LAAutilization)

Consequently, LAAI depends on the aimed performance (NR) and the observed efficiency of utilization of the limiting AA $\left(\mathrm{bc}^{-1}\right)$. Efficiency in context with the exponential model integrates digestion, absorption and post-absorptive utilisation of the LAA (Samadi and Liebert 2006, 2007), more details about model application for fish are reported elsewhere (Liebert and Benkendorff 2007a, b; Liebert 2009).

\section{RESULTS}

The survival rate of Nile tilapia after $8 \mathrm{wk}$ of feeding experimental diets was $100 \%$. All the water quality parameters were within the acceptable range for Nile tilapia dissolved oxygen, $6.56 \pm 0.27 \mathrm{mg} / \mathrm{L}$; water temperature, $28.3 \pm .4{ }^{\circ} \mathrm{C}$; ammonia, 0.070 $\pm 0.062 \mathrm{mg} / \mathrm{L}$; nitrite- $\mathrm{N}, 0.041 \pm 0.028 \mathrm{mg} / \mathrm{L}$; and $\mathrm{pH}$, $8.0 \pm 0.2$. These values were within optimum ranges for normal growth and health of juvenile Nile tilapia (Watanabe et al., 1993 and El-Shafaiet al., 2004). Average of initial body weight of Nile tilapia fingerlings fed the experimental diets at the start did not differ, indicating that groups were homogenous. Growth data from experiment study are shown in Table (2). At the end of the experimental period (56days), the group of fish fed on the supplemented diets containing methionine products (DL- MIT, DD-, LL-, DL-, and LD-Met dimers (MET1) or mixture of DL- and LD- methionine (MET2) grew as well or better than the group of fish fed the control diet. Diets 3,5 and 7 had significantly $(P<0.05)$ higher final body weight than the rest of the experimental groups. However, the lowest final body weight $(29.9 \mathrm{~g})$ was achieved in the group of fish fed on the control diet.Analysis of variance for weight gain (WG) and (SGR) followed the same trend as in final body weight. However, the increasing of methionine level up to $7 \mathrm{~g} \mathrm{~kg}^{-1}$ (dry diet) in diets $3 ., 5$ and 7 had significantly $(\mathrm{P}<0.05)$ higher SGR than the rest of experimental groupscompared to control diet Table 2 . There was a significant $(\mathrm{P}<0.05)$ improvement in (FCR) and (PER) when the feeds were supplemented with DL-MITorDD-,LL-,DL-, and LD-Metdimmers (MET1)or mixture of DL- and DL- methionine as compared with the non-supplemented of protein diets. Protein retention, measured as protein retention efficiency (PRE), was better in diets supplemented by different products of methionine compared to the control or diet 2 . The average of feed conversion ratio (FCR) in fish groups fed on diets 3 and 5 followed by groups of fish fed on diets 7 were significantly $(\mathrm{P}<0.05)$ improved in comparison with the other groups and better than the control diet. The FCR was found to be 1.91 (control diet), 1.79, 1.61, 1.73, 1.68, 1.75 and 1.66, respectively. These results showed that the best $(\mathrm{P}<0.05)$ FCR values were obtained by groups of fish fed on diet 3, 5 followed by diet 7 . The best FCR values observed with diets supplemented with bymethionine productat level of $0.30 \%$ (DLMIT or DD-,LL-,DL-, and LD-Met dimmers(MET1)or mixture of DL- and DLmethionine (MET2) suggestingthat addition of methionine product improved feed utilization.The PER found to be $2.47,2.47$ and 2.42 respectively. These results indicate that the best $(\mathrm{P}<0.05)$ PER values were obtained by groups of fish fed on diet 3 , 5 followed by diets 7 . The efficiency of different methionine product were confirmed by results of protein quality (PER) evaluation as yielded from application of on an exponential N-utilization model, eliminating the influence of varying feed intake on response of protein deposition(Table 4 ). The results of PER in fish group fed on diet 5, followed by groups fed on diets 3 and 7 were significantly $(\mathrm{P}<0.05)$ improved in comparison with the other groups and better than the control diet. This indicates that the best results of PER (37.5\%) obtained by group of fish fed on diet 5 which was supplemented by DL-, DD-,LL,DL-, and LD-Met dimmers at level of $0.30 \%\left(7 \mathrm{~g} \mathrm{~kg}^{-1}\right.$ MET1). Body composition data of the fish fed diets with various levels of methionine products in the diet are presented in Table 3. Data clearly indicate that various levels of dietary Methionine had significant $(\mathrm{P}<0.05)$ effect on the body composition of $\mathrm{O}$. niloticus. Dry matter content remained almost similar among the groups of fish fed on experimental diets except group of fish fed on diet 7 which showed low dry matter content. Ash content was decreased significantly $(\mathrm{P}<0.05)$ among the groups receiving diets up to $7 \mathrm{~g} \mathrm{~kg}^{-1}$ Methionine in the diet. Body protein tended to increase significantly $(\mathrm{P}<0.05)$ with increasing dietary methionine concentrations up to $7 \mathrm{~g} \mathrm{~kg}^{-1}$ of the diet (Diet 7). However, significant (P $<0.05)$ in body lipid content was noted for those fed diet with $7 \mathrm{~g} \mathrm{~kg}^{-1}$ Methionine (Diet 7) as compared with control diet. 
Table 2. Growth data of tilapia fingerling fed experimental diets limiting in methionine supply

\begin{tabular}{lccccccc}
\hline \multirow{2}{*}{ Parameters } & $\mathbf{7}$ & $\mathbf{5}$ & $\mathbf{D i e t}$ \\
\cline { 2 - 7 } & $\mathbf{1}$ & $\mathbf{2}$ & $\mathbf{3}$ & $\mathbf{4}$ & $\mathbf{5}$ & $\mathbf{6}$ & $\mathbf{7}$ \\
\hline $\begin{array}{l}\text { Initial weight } \\
(\mathrm{g})\end{array}$ & 13.48 & 13.36 & 13.46 & 13.5 & 13.31 & 13.45 & 13.36 \\
$\begin{array}{l}\text { Final weight } \\
(\mathrm{g})\end{array}$ & $29.9 \pm 1.9^{\mathrm{c}}$ & $30.8 \pm 2.2^{\mathrm{ab}}$ & $33.13 \pm 2.2^{\mathrm{ab}}$ & $31.7 \pm 1.8^{\mathrm{ab}}$ & $32.3 \pm 1.4^{\mathrm{ab}}$ & $31.6 \pm 1.4^{\mathrm{ab}}$ & $32.3 \pm 1.7^{\mathrm{a}}$ \\
$\mathrm{WG}^{1}(\%)$ & $122 \pm 14^{\mathrm{c}}$ & $130 \pm 16^{\mathrm{ab}}$ & $146 \pm 15^{\mathrm{a}}$ & $134 \pm 13^{\mathrm{ab}}$ & $143 \pm 11^{\mathrm{ab}}$ & $134 \pm 11^{\mathrm{ab}}$ & $142 \pm 13^{\mathrm{ab}}$ \\
$\mathrm{SGR}^{2}(\% / \mathrm{d})$ & $1.42 \pm 0.1^{\mathrm{c}}$ & $1.49 \pm 0.1^{\mathrm{b}}$ & $1.60 \pm 0.2^{\mathrm{a}}$ & $1.52 \pm 0.1^{\mathrm{b}}$ & $1.58 \pm 0.9^{\mathrm{a}}$ & $1.52 \pm 0.1^{\mathrm{b}}$ & $1.58 \pm 0.8^{\mathrm{a}}$ \\
Feed intake $_{(\mathrm{g})}$ & $787 \pm 69^{\mathrm{a}}$ & $798 \pm 90^{\mathrm{a}}$ & $791 \pm 88^{\mathrm{a}}$ & $786 \pm 53^{\mathrm{a}}$ & $775 \pm 33^{\mathrm{a}}$ & $793 \pm 15^{\mathrm{a}}$ & $783 \pm 42^{\mathrm{a}}$ \\
$\mathrm{FCR}^{3}(\mathrm{~g} / \mathrm{g})$ & $1.91 \pm 0.1^{\mathrm{c}}$ & $1.79 \pm 0.1^{\mathrm{ab}}$ & $1.61 \pm 0.0^{\mathrm{a}}$ & $1.73 \pm 0.1^{\mathrm{a}}$ & $1.68 \pm 0.9^{\mathrm{a}}$ & $1.75 \pm 0.1^{\mathrm{ab}}$ & $1.66 \pm 0.1^{\mathrm{a}}$ \\
$\operatorname{PER}^{4}(\mathrm{~g} / \mathrm{g})$ & $2.09 \pm 0.1^{\mathrm{c}}$ & $2.21 \pm 0.1^{\mathrm{bc}}$ & $2.47 \pm 0.1^{\mathrm{a}}$ & $2.30 \pm 0.1^{\mathrm{b}}$ & $2.47 \pm 0.1^{\mathrm{a}}$ & $2.27 \pm 0.1^{\mathrm{b}}$ & $2.42 \pm 0.12^{\mathrm{a}}$ \\
$\operatorname{PRE}^{5}(\%)$ & $30.8 \pm 1.9^{\mathrm{c}}$ & $33.1 \pm 1.0^{\mathrm{bc}}$ & $36.8 \pm 0.8^{\mathrm{a}}$ & $34.5 \pm 1.1^{\mathrm{ab}}$ & $37.5 \pm 0.9^{\mathrm{a}}$ & $35.5 \pm 1.0^{\mathrm{ab}}$ & $35.7 \pm 0.9^{\mathrm{ab}}$ \\
\hline
\end{tabular}

Values in the same row with a common superscript are not significantly different $(\mathrm{P}<0.05)$.

${ }^{1)}$ Weight gain $=100 \times($ final body weight- initial body weight $) /$ initial body weight.

${ }^{2)}$ Spacific growth rate $=(\mathrm{Ln}$. Final body weight- Ln. Initial body weight $) \times 100 /$ experimental period (days)

${ }^{3)}$ Feed conversion ratio $=\mathrm{g}$ dry feed consumed/g wet weight gain.

4) Protein efficiency ratio = fish wet weight gain/protein intake.

${ }^{5)}$ Protein retention efficiency $=100 \times$ (final body protein - initial body protein)/total protein fed.

Table 3. Whole body composition of fingerling tilapia ( $\mathrm{g} \mathrm{kg-1}$ dry matter)

\begin{tabular}{lcccccccc}
\hline Diet & $\begin{array}{c}\text { Initia } \\
\mathbf{l}\end{array}$ & $\mathbf{1}$ & $\mathbf{2}$ & $\mathbf{3}$ & $\mathbf{4}$ & $\mathbf{5}$ & $\mathbf{6}$ & $\mathbf{7}$ \\
\hline $\begin{array}{l}\text { Dry } \\
\text { matter }\end{array}$ & 174.2 & $220 \pm 0.12^{\mathrm{b}}$ & $222 \pm 0.34^{\mathrm{b}}$ & $220 \pm 0.76^{\mathrm{b}}$ & $223 \pm 0.16^{\mathrm{b}}$ & $222 \pm 0.50^{\mathrm{b}}$ & $229 \pm 0.44^{\mathrm{a}}$ & $215 \pm 0.57^{\mathrm{c}}$ \\
$\begin{array}{l}\text { Crude } \\
\text { protein }\end{array}$ & 688.6 & $611 \pm 0.70^{\mathrm{c}}$ & $14 \pm 0.70^{\mathrm{c}}$ & $620 \pm 0.70^{\mathrm{b}}$ & $612 \pm 1.41^{\mathrm{c}}$ & $623 \pm 2.12^{\mathrm{b}}$ & $613 \pm 1.41^{\mathrm{c}}$ & $630 \pm 2.8^{\mathrm{a}}$ \\
$\begin{array}{l}\text { Crude } \\
\text { lipid }\end{array}$ & 109.6 & $257 \pm 0.71^{\mathrm{a}}$ & $230 \pm 0.78^{\mathrm{d}}$ & $236 \pm 0.75^{\mathrm{b}}$ & $239 \pm 0.9^{\mathrm{b}}$ & $229 \pm 0.6^{\mathrm{e}}$ & $233 \pm 0.5^{\mathrm{c}}$ & $227 \pm 0.8^{\mathrm{e}}$ \\
Ash & 201.8 & $132 \pm 1.5^{\mathrm{d}}$ & $156 \pm 0.9^{\mathrm{a}}$ & $144 \pm 0.0^{\mathrm{c}}$ & $149 \pm 1.6^{\mathrm{b}}$ & $148 \pm 0.9^{\mathrm{b}}$ & $154 \pm 1.5^{\mathrm{a}}$ & $143 \pm 1.1^{\mathrm{c}}$ \\
\hline
\end{tabular}

Values in the same row with a common superscript are not significantly different $(\mathrm{P}<0.05)$.

Table 4.Model parameters data of tilapia fingerling fed experimental diets limiting in methionine supply

\begin{tabular}{|c|c|c|c|c|c|c|c|}
\hline \multirow{2}{*}{$\begin{array}{l}\text { Model } \\
\text { parameters }\end{array}$} & \multicolumn{7}{|c|}{ Diet } \\
\hline & 1 & 2 & 3 & 4 & 5 & 6 & 7 \\
\hline Daily $N$-intake $^{1}$ & $289 \pm 19^{a}$ & $285 \pm 24^{\mathrm{a}}$ & $280 \pm 23^{\mathrm{a}}$ & $283 \pm 15^{\mathrm{a}}$ & $275 \pm 86^{\mathrm{a}}$ & $285 \pm 4^{\mathrm{a}}$ & $279 \pm 10^{\mathrm{a}}$ \\
\hline Daily N-retention $^{2}$ & $160 \pm 7^{b}$ & $166 \pm 8^{\mathrm{ab}}$ & $172 \pm 7^{\mathrm{a}}$ & $168 \pm 7^{\mathrm{ab}}$ & $171 \pm 5^{\mathrm{a}}$ & $172 \pm 5^{\mathrm{a}}$ & $170 \pm 6^{\mathrm{a}}$ \\
\hline $\begin{array}{l}\text { Protein quality } \\
\mathrm{b}\left(* 10^{6}\right)\end{array}$ & $1845 \pm 96^{c}$ & $1959 \pm 15^{\mathrm{bc}}$ & $2120 \pm 98^{\mathrm{ab}}$ & $2014 \pm 117^{\mathrm{ab}}$ & $2159 \pm 97^{a}$ & $2062 \pm 102^{\mathrm{ab}}$ & $2073 \pm 89^{\mathrm{ab}}$ \\
\hline $\begin{array}{l}\text { Met efficiency bc- } \\
1\left(* 10^{6}\right)\end{array}$ & $1205 \pm 62^{c}$ & $913 \pm 54^{b}$ & $763 \pm 35^{\mathrm{a}}$ & $944 \pm 55^{b}$ & $774 \pm 35^{\mathrm{a}}$ & $963 \pm 47^{b}$ & $746 \pm 32^{a}$ \\
\hline $\begin{array}{l}\text { Met content cMet } \\
(\mathrm{g} / 16 \mathrm{gN})\end{array}$ & 1.53 & 2.14 & 2.77 & 2.13 & 2.78 & 2.14 & 2.77 \\
\hline
\end{tabular}

Values in the same row with a common superscript are not significantly different $(\mathrm{P}<0.05)$

${ }^{1} \mathrm{NI}\left(\mathrm{mg} / \mathrm{BWkg}^{0.67}\right),{ }^{2} \mathrm{NR}\left(\mathrm{mg} / \mathrm{BWkg}^{0.67}\right)$

\section{DISCUSSION}

The utilization of crystalline amino acids in practical diets of fish depends on the species ability to absorb and use such amino acids for protein synthesis as well as for other physiological functions. In tilapia, varying results have been obtained with crystalline amino acid supplementation. Growth performance of Oreochromisniloticuswas improved when a $35 \%$ protein diet formulated from casein was supplemented with either arginine and lysine or tryptophan and methionine (Teshimaet al., 1986). Taconet al. (1983) reported that growth of Nile tilapia was improved to a level comparable to that obtained from a fish meal-based diet when $0.8 \% \mathrm{D}$, Lmethionine was supplemented to a diet in which $75 \%$ of brown fish meal was replaced by soybean meal. Further studies with tilapia, which were recently 
reported, confirm such findings (Jintasatapornet al., 2010 and Zhu et al., 2010). These results are in agreement with present study, which reported that weight gain of juvenile Nile tilapia was increased significantly as Methionine levels increased by supplementation of crystalline Methionine, indicating that juvenile Nile tilapia could use crystalline Methionine efficiently when Methionine levels in practical diets were deficient. However, in other fish species, the supplementation of essential amino acid (EAA) to a low-protein diet reported in channel catfish (Li and Robinson, 1998) and rainbow trout (Yamamoto et al., 2005), showed that the supplementation of EAA in an insufficient protein diet improved the feed efficiency but did not enhance fish growth. While, (Williams et al., 2001) with Asian sea bass, demonstrated that the crystallineEAA supplementation to an EAA deficient diet increased fish growth and the response was more pronounced for the low protein diet. Yang et al., (2010) demonstrated significant improvement of growth and feed utilization of grass carp can be achieved by L-Lysine sulphate and MHA-Ca supplementation. WG and PR of the tested group improved $11.4 \%$ and $8.3 \%$, respectively, while FCR decreased $9.6 \%$ in comparison with control diet. In contrary with these findings, growth and feed efficiency of hybrid tilapia, $O$. niloticusxOreochromisaureus, were not improved when either methionine and lysine or threonine were added to a $24 \%$ protein diet containing soybean meal as the main protein source (Liouet al., 1986). Same trend was reported by (Nguyen 2007 and Nguyen, 2009) which demonstrated that supplementation of methionine to practical diets, did not improve growth, survival and, feed conversion ratio of juvenile tilapia, Oreochromis spp. This may be because methionine levels in non-supplemented diets have met the requirement. It is obvious that the methionine level of the control diet are further reduced from their requirements which mainly explained the significant improvement of PER and PRE, as well as the apparent decrease of FCR in the tested group compared with the control group (Table 2). The improved of PRE in this study is in agreement with (Sveieret al., 2001) who reported that supplementation of D-methionine showed better protein utilization than L-methionine when measured as PPV in diet of Atlantic salmon (Salmon salar L.) . Same trend was reported by (Yamamoto et al., 2005) who suggested that the EAA supplementation to lowprotein diets in rainbow trout improves dietary amino acid utilization and results in an increase of body protein deposition, as similarly noted in gilthead sea bream (Peres and Oliva-Teles, 2009). The body composition of Nile Tilapia is another important aspect, which needed to pay attention to in this experiment (Table 3). The significantly lower whole body lipid and the higher protein of tested fish compared with the control fish indicated a better health condition and higher economic value of tilapia were obtained by feeding supplemental EAA. However, such result of body lipid was contradictory with an earlier report of grass carp (Wang et al., 2005) and studies of redseabream and freshwater catfish (Chatzifotiset al., 1996 andTantikitti and Chimsung, 2001) which had higher body lipid content occurred in the lysine supplemented groups. The authors suggest that the amino acids in excess from disproportionate absorption or the part of lysine beyond optimal level would be no longer used for transformation into protein or protein synthesis, but was consumed in catabolism and provided the carbon skeletons for lipid synthesis and deposited as tissue fat, mainly at mesentery. On contrary, opposite trend of whole body lipid content in the present study may be attributed to the insufficient supplementation of methionine, which makes such metabolic pathway impossible. This can be confirmed by the markedly increased whole body protein level of the tested fish, as also noted by Peres and Oliva-Teles (2009) in gilthead sea bream and Yang et al. (2010) with Grass Carp (Ctenopharyngodonidella).

\section{CONCLUSION}

Supplementation of either Met source yielded dose dependent responses, suggesting general evidence for supplemental amino acids being utilized for growth and protein deposition in fish. Making use of the nitrogen utilization model, the observed efficiency of total Met in diets supplemented with different Met-sources was lower when compared with the non-supplemented basal diet. This observation provides some advice, that utilization of added Met was somewhat lower than utilization of the proteinbound AA. These observations need more investigations in context with the specific features of protein metabolism in fish, comparing DL-Met with the new Met-sources under study (MET1, MET2), an advantage was established of growth and protein utilization as PRE of Nile tilapia can be achieved by the new Met-sources in this investigations.

\section{REFERENCES}

Alam, M.S., S. TeshimaandM. Ishikawa 2001.Methionine requirement of juvenile Japanese founder Paralichthysolivaceus estimated by the oxidation of radioactive methionine. Aquaculture, 7:201-209

Cho, C.Y.,andD.P. Bureau, 2001.A review of diet formulation strategies and feeding systems to reduce excretory and feed wastes in aquaculture.Aquaculture Research 32:349-360

Cowey, C.B., 1992. Nutrition: estimation requirements of rainbow trout. Aquaculture 100:177-189

Chatzifotis, S., T. Takeuchiand T. Seikai,1996. The effect of dietary carnitinesupplementationon growth of red sea bream (Pagrus major) 
fingerlings at two levels of dietary lysine. Aquaculture 147: 235-248.

Denstadli, V.,

SkredeA.KrogdahlS.SahlstrømandT.Storebakken, 2006. Feed intake, growth, feed conversion, digestibility, enzyme activities and intestinal structure in Atlantic salmon (Salmosalar L.) fed graded levels of phytic acid. Aquaculture256:287295

Duncan, N. B., 1955. Multiple range and multiple Ftest. Biometrics 11:1-24

El-Shafai, S.A., F.A. El-Gohary F.A. Nasr N.P van der Steenand H.J. Gijzen,2004.Chronic ammonia toxicity to duckweed-fed tilapia (Oreochromisniloticus). Aquaculture 232:117127

Goff, J.Band D.M. Gatlin, 2004. Evaluation of different sulfur amino acid compounds in the diet of red drum, sciaenopsacellatus, andsparing value of cystine for methionine. Aquaculture, 241:465477

Helland, S.J, B. HatlenandB.Grisdale-Helland, 2006. Changes in the utilization ofenergy and amino acids caused by feed intake level-implications for amino acid requirement studies. Proceedings of the XIIthInternational Symposium on Fish Nutrition and Feeding, Biarritz,France, 75.

Jackson, A.J and B.S. Capper, 1982.Investigations into the requirements of tilapia Sarotherodonmossambicus for dietary methionine, lysine and arginine in semi-synthetic diets. Aquaculture, 29:289-297

Jintasataporn, O., P. Tabthipwon D,Sangsue and A. Lemme, 2010.Fishmeal reduction in diets for sexreversed red hybrid tilapia (Oreochromis spp.) with focus on amino acid supply. 14thInternational Symposium on Fish Nutrition and Feeding, Qingdao, China, May 31 to June 4:389

Kasper, C.S., M.R. WhiteandP.B. Brown,2000. Choline is required by tilapia when methionine is not in excess. Journal of Nutrition, 238:238-242.

Kaushik, S.J and I. Seiliez, 2008.Current knowledge of protein and amino acid nutrition and metabolism in fish.Proceedings of International Symposium on Fish Nutrition andFeeding, Florianópolis, Brazil. Book of Abstracts, 9

Li, M.H and E.H. Robinson, 1998.Effects of supplemental lysine and methionine in low protein diets on weight gain and body composition of young channel catfish Ictaluruspunctatus. Aquaculture, 163:297-307.

Liebert, F and K, Benkendorff, 2007a.Modeling lysine requirements of Oreochromisniloticus due to principles of the diet dilution technique.Aquaculture ,267:100-110

Liebert, F, 2009. Amino acid requirement studies in Oreochromisniloticus by application of principles of the diet dilution technique. Journal of Animal Physiology and Animal Nutrition DOI: 10.1111/j.1439-0396.2008.00869.
Liebert, F and K. Benkendorff, 2007b.Modeling of threonine and methionine requirements of Oreochromisniloticus due to principles of the diet dilution technique. Aquaculture Nutrition, 13:397406

Liebert, F., S. Angela and M. Khaled, 2006.Assessment of nitrogen maintenance requirement and potential for protein deposition in juvenile Tilapia genotypes by application of an exponential nitrogen utilization mode. Aquaculture, 4:1346-1355

Lim, C., 1996.Substitution of cottonseed meal for marine animal protein in diets for Penaeusvannamei. Journal of WorldAquaculture Society, 27:402-409

Maina, J.G., R.M. Beames, D. Higgs, P.N. Mbugua,G. Iwama and S.M. Kisia, 2003. Partial replacement of fishmeal with sunflower cake and corn oil in diets for tilapia Oreochromisniloticus (Linn): effect on whole body fatty acids. Aquaculture Research,34:601-609

Nguyen, T.N.,2009.Methionine Requirement in Practical Diets of Juvenile Nile Tilapia, Oreochromisniloticus. Journal of World Aquaculture Society, 40(3):410-416

Nguyen, T.N andD.A. Davis, 2008.Re-evaluation of total sulphur amino acid requirement anddetermination of replacement value of cystine for methionine in semi-purified diets of juvenile Nile tilapia, Oreochromisniloticus. Aquaculture Nutrition, 15:247-253

Nguyen, T.N.,2007. Total sulfur amino acid requirement and its application to practical diets for juvenile tilapia (Oreochromisspp.). $\mathrm{PhD}$ dissertation.Auburn University, Auburn, Alabama, USA.

NRC, 2011.Nutrient Requirements of Fish.National Research Council, National Academy Press, Washington D.C., USA.

Ogunji, J.O, M. Wirth and B. Rennert, 2005.Assessing the dietary amino acid requirements of tilapia, Oreochromisniloticusfingerlings.Journal of aquaculture in the tropics, 20(4):241-252

Peres, Hand A. Oliva-Teles, 2009. The optimum dietary essential amino acid profile for gilthead seabream (Sparusaurata) juveniles. Aquaculture, 296:81-86.

Robbins, K.R,H.W. Norton and D.H. Baker, 1979.Estimation of nutrient requirements from growth data.Journal of Nutrition, 109:1710-1714

Samadiand F. Liebert, 2006.Modelling of threonine requirement in fast growing chickens depending on age, sex, protein deposition and efficiency of dietary threonine utilization.Poultry Science, 85:1961-1968

Samadiand F. Liebert, 2007.Lysine requirement of fast growing chickens - effects of age, sex, level of protein deposition and dietary lysine efficiency. Journal of Poultry Science,44:63-72 
Santiago, C.B and R.T. Lovell, 1988.Amino acid requirements for growth of Nile tilapia.Journal of Nutrition, 118:1540-1546

Shearer, K.D.,2000. Experimental design, statistical analysis and modeling of dietary nutrient requirement studies for fish: a critical review. Aquaculture Nutrition,6:91-102

Sveier, H.,H.S.Nordaê,G.E.berge and E.Lied, 2001. Dietary inclusion of crystalline D- and Lmethionine: effects on growth, feed and protein utilization, and digestibility in small and large Atlantic salmon (Salmon salar L.). Aquaculture Nutrition, 7:169-181

Tacon, A.G.J.,K.Jauncey, A.Falaye, M.Pentah, I.MacGowenand E. Stafford. 1983. The use of meat and bone meal and hydrolyzed feather meal and soybean meal in practical fry and fingerling diets for Oreochromisniloticus. P. 356-365 in J. Fishelton and Z. Yaron, editors.Proceedings of the 1stInternational Symposium on Tilapia in aquaculture. Tel Aviv University, Tel Aviv, Israel

Tacon, A.G.J and A.J. Jackson, 1985. Utilization of conventional and unconventional protein sources in practical fish feeds. In: Nutrition and Feeding in Fish (Cowey, C.B., Mackie, A.M. and Bell, J.G. eds), pp. 119-145. Academic Press, London

Tantikitti, Cand N.Chimsung, 2001.Dietary lysine requirement of freshwater catfish (MystusnemurusCuv. and Val.). Aquaculture Research, 32:135-141

Wang, S., Y.J. Liu LX.TianMQ. Xie HJ. Yang Y. Wangand GY.Liang 2005. Quantitative dietary lysine requirement of juvenile grass carp Ctenopharyngodonidella. Aquaculture, 249, 419429

Teshima, S., A.Kanazawa and Y. Uchiyama 1986.Effect of several protein sources and other factors on the growth of Tilapia nilotica.Bulletin of the Japanese Society of Scientific Fisheries, 52:525-530

Watanabe, W.O, D.H.Ernst M. P.ChasarR. I.Wicklund and B.L.Olla,1993.The effects of temperature and salinity on growth and feed utilization of juvenile, sex-reversed male Florida red tilapia cultured in a recirculating system. Aquaculture, 112:309-320

Were, K.E., 1989.Determination of the tryptophan requirement of the juvenile rainbow trout using the indication oxidation technique. MSc. Thesis, University of Guelph, Guelph, Canada

Williams, K.,C.Barlow and L.Rodgers, 2001.Efficiency of crystalline and protein-bound amino acids for amino acid enrichment of diets for barramundi/Asian seabass (LatescalcariferBloch). 32: 415-429

Wilson, M.F., E.P. Luiz M.B. Margarida A.C.Pezzato and R.B.Valéria, 2004. Use of ideal protein concept for precision formulation of amino acid levels in fish meal free diets for juvenile Nile tilapia (Oreochromisniloticus L.). Aquaculture Research,35:1110-1116

Wilson, R.P., 2003.Amino acid requirements of finfish and crustaceans. In: JPFD'Mello (ed), Amino Acids in Animal Nutrition, CABI Publ., Wallingford, UK pp. 427-447

Yamamoto, T., T.Sugita and H.Furuita, 2005. Essential amino acid supplementation to fish mealbased diets with low protein to energy ratios improves the protein utilization in juvenile rainbow trout Oncorhynchusmykiss. Aquaculture, 246: 379-391

Yang, H.J., Y.J. Liu,L.X. Tian, G.Y. Liang and H.R. Lin, 2010.Effects of Supplemental Lysine and Methionine on Growth Performance and Body Composition for Grass Carp (Ctenopharyngodonidella).American Journal of Agricultural and Biological Sciences,5(2): 222227

Zhou, Q.C., Z.H.Wu and B.P.Tan, 2006.Optimal dietary methionine requirement for juvenile Cobia (Rachycentroncanadum). Aquaculture, 3:1-7

Zhu, X., M. Jiang and A.Lemme, 2010.Responses of juvenile Nile tilapia (Oreochromisniloticus) to supplemental methionine. $14^{\text {th }}$ International Symposium on Fish Nutrition and Feeding, Qingdao, China, May 31 to June 4: 486. 


\section{كفاءة استخدام مصادر الميثيونين المختلفة في علائق أصبعيات البلطى النيلى منخفضة الميثيونين}

خالد أحمد السبي على محله و فرنك ليبيرت

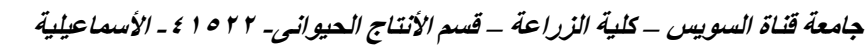
جامعة جورج أوجست ـكلية الزراعة ـقسم فسيولوجيا تغذية الحيوان- جوتتجن_ألمانيا

أجريت تجربة لتقييم استخدام مصادر مختلفة للحامض الأميني الميثيونين في تحسين شكل وتركيب الأحماض الأمينية وتأثنير ها على أداء النمو النيا

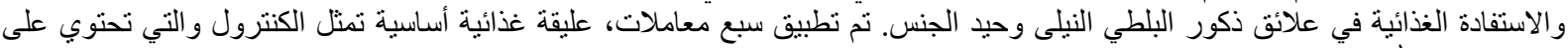

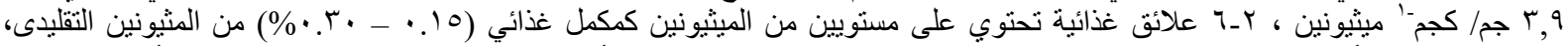

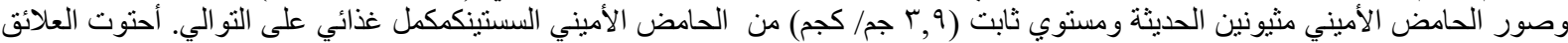

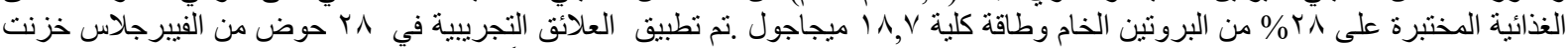

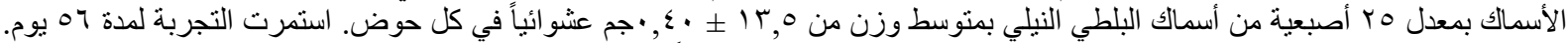

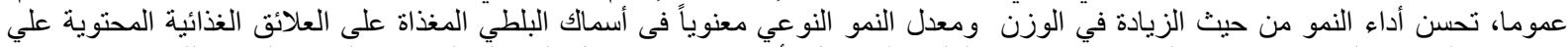

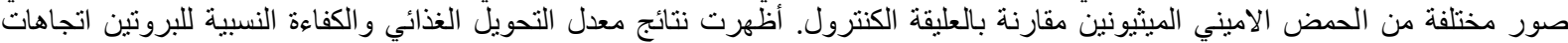

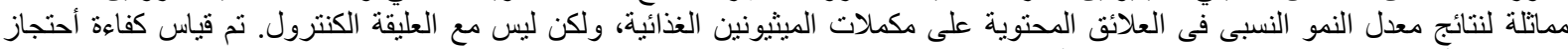

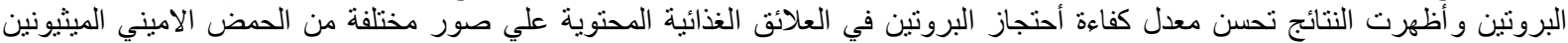

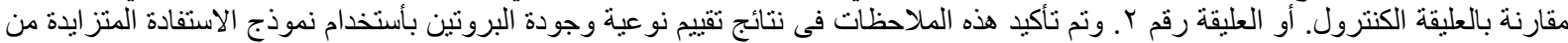

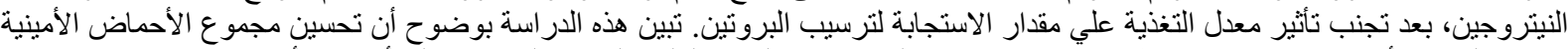

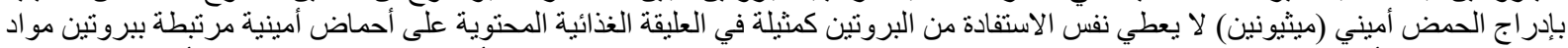

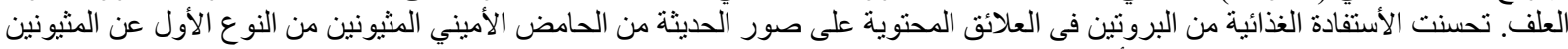

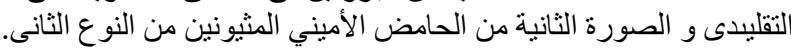

